\title{
Selectivity of Metarhizium anisopliae and Beauveria bassiana to adults of Telenomus podisi (Hymenoptera: Scelionidae)
}

\section{Seletividade de Metarhizium anisopliae e Beauveria bassiana para adultos de Telenomus podisi (Hymenoptera: Scelionidae)}

\author{
Lucas Battisti ${ }^{1}$; Jheniffer Valmira Warmling ${ }^{1}$; Claudinei de Freitas Vieira ${ }^{1}$; \\ Darlin Henrique Ramos de Oliveira ${ }^{1}$; Yuri Renan Alves de Lima ${ }^{1}$; Adeney de Freitas \\ Bueno $^{2}$; Michele Potrich ${ }^{3}$; Everton Ricardi Lozano ${ }^{3 *}$
}

Highlights

Entomopathogenic fungi can decrease the longevity of female Telenomus podisi.

Telenomus podisi parasitism is not affected by exposure to entomopathogenic fungi.

The emergence of $T$. podisi offspring may reduce when the female is exposed to fungi.

\begin{abstract}
The selectivity of entomopathogenic fungi to non-target organisms needs to be considered in Integrated Pest Management (IPM), because even though they are biological control agents, if used incorrectly, they can negatively alter the functioning of agroecosystems. Therefore, studies that assess the selectivity of these fungi to beneficial organisms are extremely important. The objective of this work was to evaluate the selectivity of Metarhizium anisopliae (Metarri ${ }^{\circledR}$ ) and Beauveria bassiana (Boveri ${ }^{\circledR}$ ) to adults of Telenomus podisi Ashmead (Hymenoptera: Scelionidae), under laboratory conditions. The products were evaluated on adult females of T. podisi, at the concentrations recommended by the manufacturer. To this, $0.2 \mathrm{~mL}$ of suspensions of each product and control (treatments) were applied to the inner surface of glass tubes, and then a female T. podisi was placed in it ( $\leq 48 \mathrm{~h}$ of emergence). After $24 \mathrm{~h}$ of contact, cards with 25 eggs of Euschistus heros Fabricius (Hemiptera: Pentatomidae) were offered for $24 \mathrm{~h}$ (COF24). After this period, the COF24 were withdrawn. After $72 \mathrm{~h}$ of contact of the female with the tube surface, new $E$. heros egg cards
\end{abstract}

1 Researcher at the Biological Control Laboratory, LABCON, Coordination of Biological Sciences, Universidade Tecnológica Federal do Paraná, Campus Dois Vizinhos UTFPR-DV, Dois Vizinhos, PR, Brazil. E-mail: lucasbattisti@ gmail.com; jheniffervalmira@hotmail.com; yurirenanlima@gmail.com; claudineidfv@gmail.com

2 Researcher at the Entomology Laboratory, Empresa Brasileira de Pesquisa Agropecuária, EMBRAPA, Londrina, PR, Brazil. E-mail: adeney.bueno@embrapa.br

3 Profs. Drs. and Researcher at the Biological Control Laboratory, LABCON, Coordination of Biological Sciences, Universidade Tecnológica Federal do Paraná, Campus Dois Vizinhos, UTFPR-DV, Dois Vizinhos, PR, Brazil. E-mail: evertonloz@gmail.com; profmichele@gmail.com

* Author for correspondence

Received: Jun. 05, 2021 - Approved: Dez. 07, 2021 
were made available (COF72) for $24 \mathrm{~h}$ for $T$. podisi ovipositioning. The mortality of $T$. podisi females was evaluated daily to determine longevity, percentage of parasitism and emergence, sex ratio, and egg-adult period of the T. podisi offspring. Metarri ${ }^{\circledR}$ and Boveril ${ }^{\circledR}$, considered selective for adult females of T. podisi, did not negatively affect most of the parameters evaluated.

Key words: Biological control. Pest insects. Egg parasitoid. Enthomopatogenic fungi.

\section{Resumo}

A seletividade de fungos entomopatogênicos a organismos não-alvo deve ser considerada no Manejo Integrado de Pragas (MIP), pois mesmo sendo agentes de controle biológico, se utilizados de forma incorreta, podem alterar negativamente o funcionamento dos agroecossistemas. Portanto, estudos que avaliam a seletividade desses fungos a organismos benéficos são extremamente importantes. O objetivo deste trabalho foi avaliar a seletividade de Metarhizium anisopliae (Metarril ${ }^{\circledR}$ ) e Beauveria bassiana (Boveril ${ }^{\circledR}$ ) a adultos de Telenomus podisi Ashmead (Hymenoptera: Scelionidae), em condições de laboratório. Os produtos foram avaliados em fêmeas adultas de T.podisi, nas concentrações recomendadas pelo fabricante. Para tanto, $0,2 \mathrm{~mL}$ das suspensões de cada produto e controle (tratamentos) foram aplicados na superfície interna dos tubos de vidro, sendo então colocada uma fêmea de $T$. podisi ( $\leq 48 \mathrm{~h}$ de emergência). Após 24 h de contato, cartões com 25 ovos de Euschistus heros Fabricius (Hemiptera: Pentatomidae) foram oferecidos por 24 h (COF24). Após esse período, o COF24 foi retirado. Após 72 h de contato da fêmea com a superfície do tubo, foram disponibilizadas novas cartelas de ovos de E. heros (COF72) por $24 \mathrm{~h}$ para oviposição de T. podisi. A mortalidade de fêmeas de T. podisi foi avaliada diariamente para determinar longevidade, porcentagem de parasitismo e emergência, proporção sexual e período de ovo-adulto da prole de T. podisi. Metarril ${ }^{\circledR}$ e Boveril ${ }^{\circledR}$ foram considerados seletivos para fêmeas adultas de T. podisi, não afetaram negativamente a maioria dos parâmetros avaliados.

Palavras-chave: Controle biológico. Insetos-praga. Parasitoide de ovo. Fungos entomopatogênicos.

\section{Introduction}

The excessive use of synthetic phytosanitary products has increased the negative impacts on the environment, and with that, organic production has been gaining ground as a more sustainable alternative for cultivation in the global market (Nodari \& Guerra, 2015). Soybeans in particular have stood out in terms of productivity and cultivated area, compared to other oilseeds in global organic production (FIBL \& IFOAM, 2019). In organic crops, natural biological control is generally greater due to the non- use of synthetic chemical insecticides, which are generally less selective. However, when intervention for pest management is necessary, the lack of efficient organic alternatives is still a challenge. Thus, augmentative biological control (ABC) has been developed in recent decades, using entomopathogens, parasitoids, and predators, which can be applied massively on crops as an effective pest control method to replace synthetic phytosanitary products (Bueno, Bueno, Parra, Vieira, \& Oliveira, 2010; Parra, 2014, 2019; van Lenteren, Bolckmans, Köhl, Ravensberg, \& Urbaneja, 2018). 
In $A B C$, egg parasitoids are considered as the main natural enemies of stink bugs of the Pentatomidae family, especially the species Telenomus podisi Ashmead (Hymenoptera: Scelionidae). Responsible for more than $80 \%$ of the parasitism observed in eggs of the brown stink bug Euschistus heros Fabricius (Hemiptera:Pentatomidae) (Pacheco \& CorrêaFerreira, 2000; Tognon, Sant'Ana, \& Jahnke, 2013) and capable of parasitizing 104 to 211 eggs of this insect-pest (Pacheco \& CorrêaFerreira, 2000; Silva, Bueno, Neves, \& Favetti, 2018), this biological control agent has been a commercial product in Brazil since 2019. In addition to the parasitoids, products based on entomopathogenic fungi are also being used in the country for the biological control of the soybean brown stink bug, with so far seven registered products formulated with isolates of $B$. bassiana and M. anisopliae (Sistema de Agrotóxicos Fitossanitários (AGROFIT), 2021). Studies have been carried out to select and characterize new fungal isolates that have the potential to infect $E$. heros, since the natural infection by entomopathogenic fungi is generally insufficient for population control of this insect; thus, requiring flooding application (Silva-Santana, Alves, Ferreira, \& Bonini, 2021; Nora et al., 2021). With this growth in the use of entomopathogens comes the need to assess their lethal and sublethal effects on egg parasitoids, which in many occasions are applied in an associated way in the field (Polanczyk, Pratissoli, Dalvi, Grecco, \& Franco, 2010; Potrich et al., 2015).

The associated use of $T$. podisi and entomopathogenic fungi, such as $B$. bassiana and $M$. anisopliae, can be a necessary and efficient strategy in Integrated Pest Management (IPM), especially when target pests of these fungiare occurring together with stink bugs, targets of the parasitoid (Amaro, Bueno, Pomari-Fernandes, \& Neves, 2015). Therefore, evaluating the effect of these fungi on T. podisi is extremely important as these entomopathogens can infect egg parasitoids, causing lethal or sublethal effects (Magalhães, 1998). From this perspective, it is important to emphasize that entomopathogenic fungi can affect the non-target organisms in different ways, varying according to the form of application, the species of organism, and dosage, among other factors. Therefore, the objective of this work was to evaluate the selectivity of $M$. anisopliae and $B$. bassiana to adults of T. podisi.

\section{Material and Methods}

Commercial natural products, obtaining $T$. podisi and E. heros eggs

Two commercial natural products based on entomopathogenic fungi $M$. anisopliae (Metarril ${ }^{\circledR}$ ) and $B$. bassiana (Boveril ${ }^{\circledR}$ ) were tested at the dose recommended by the manufacturer for the control of $E$. heros (Table 1). Eggs of $E$. heros not parasitized and parasitized by $T$. podisi were acquired from a company specialized in breeding and marketing (Bug Agentes Biológicos). Nonparasitized eggs were stored in a refrigerator at a temperature of $4{ }^{\circ} \mathrm{C}$ for a maximum of two days until the experiments were carried out. Eggs parasitized by T. podisi were placed in plastic bottles (1000 $\mathrm{mL}$ volume), kept in a air-conditioned chamber $\left(26 \pm 1{ }^{\circ} \mathrm{C}, 12 \mathrm{~h}\right.$ photophase, $75 \pm 10 \%$ U.R.) for two days for the emergence of adults. To feed the adult parasitoids, a fillet of organic honey was placed on the wall of the plastic container. 
Table 1

Composition, trade name, recommended concentration and cultures used of the products tested on adults of Telenomus podisi

\begin{tabular}{ccccc} 
Composition & $\begin{array}{c}\text { Commercial } \\
\text { name }\end{array}$ & $\begin{array}{c}\text { Recommended } \\
\text { dose* }\end{array}$ & $\begin{array}{c}\text { Concentration of } \\
\text { active ingredients }\end{array}$ & Crops \\
\hline Metarhizium anisopliae & Metarril $^{\circledR}$ & $0.5 \mathrm{~kg} / \mathrm{ha}$ & $1.39 \times 10^{8}$ conidia $/ \mathrm{g}$ & Pastures/Soybeans \\
Beauveria bassiana & Boveril $^{\circledR}$ & $0.5 \mathrm{~kg} / \mathrm{ha}$ & $1 \times 10^{8}$ conidia $/ \mathrm{g}^{*}$ & Soybeans \\
\hline
\end{tabular}

* Volume of syrup considered 200 L/ha.

Effects of M. anisopliae and B. bassiana on $T$. podisi adults

For each treatment, 25 non-parasitized E. heros eggs (up to $96 \mathrm{~h}$ of age) were fixed on $1.5 \times 1.5 \mathrm{~cm}$ bond card sheets with nontoxic glue made with wheat flour and distilled water. Suspensions of entomopathogenic fungi were prepared in Becker-type flasks containing $100 \mathrm{~mL}$ of distilled water + Tween $80^{\circledR}(0.01 \%)$, according to the concentration recommended by the manufacturer (Table 1). With the aid of a micropipettor, $0.2 \mathrm{~mL}$ of solution was applied inside a sterilized glass tube (8 cm height and $2.5 \mathrm{~cm}$ diameter), ensuring that the product is evenly distributed throughout the internal region of the glass tube. Subsequently, the tubes were left in a $V \mathrm{Cco}^{\circledR}$ laminar flow chamber for approximately three hours until complete drying. In each treatment, 20 glass tubes (replications) were used, placing a copulated female $T$. podisi ( $\leq 48 \mathrm{~h}$ of emergence), with no experience of parasitism, per tube, together with a fillet of organic honey as food. In the control, the tubes were applied with $0.2 \mathrm{~mL}$ sterilized distilled water $+0.01 \%$ Tween $80^{\circledR}$ solution.
After 24 hours of contact of the females with the surface of the tube contaminated with the treatments, a card with 25 eggs of non-parasitized $E$. heros (COF24) was inserted into each of them. The tubes were closed with polyvinyl chloride (PVC) film, and placed in an air-conditioned chamber (26 \pm 1 ${ }^{\circ} \mathrm{C}, 12 \mathrm{~h}$ photophase, $75 \pm 10 \%$ U.R.). After 24 hours, the COF24 were removed and placed in other tubes, which were sealed, identified and kept in an air-conditioned chamber under the same conditions described above. The adult females were kept in the same sprayed tubes, and after 72 hours of contact of the T. podisi females with the treatments, new cards with 25 E. heros eggs (COF72) were made available, following the same procedures described above. Females of $T$. podisi were kept until they died to assess their longevity and confirm death by the fungus. The parameters evaluated were: longevity of adult females that carried out the parasitism, parasitism (\%) of eggs offered at 24 and 72 $\mathrm{h}$ of contact of females with the treatments, emergence (\%), sex ratio, and egg-adult cycle of the F1 generation. 
Parasitism was calculated considering the number of eggs per card (25) as $100 \%$. The emergence percentage $(\mathrm{Pe})$ and the sex ratio $(R)$ were calculated by the following equations according to Battisti et al. (2020):

$P p=\frac{n \cdot 100}{25}$ and $P e=\left(\frac{T e}{T o}\right) \cdot 100$ e $R=\frac{T m}{T m+T f}$, where $P p$ is the percentage of parasitism, $n$ is the number of parasitized eggs, $T e$ is the total number of emerged adults, To is the total number of parasitized eggs, and $\mathrm{Tm}$ and Tf are the total number of emerged males and females, respectively.

The longevity (L) and the eggadult period (Po) were calculated using a weighted average as per Battisti et al. (2020):

$$
\begin{gathered}
L=[(n p m \cdot d 1)+(n p m \cdot d 2)+(n p m \cdot d 3) \ldots \\
\left.+\frac{n p m \cdot d n}{T M o}\right] \text { and } P o=[(n p \cdot d 1)+(n p \cdot d 2)+ \\
\left.(n p \cdot d 3) \ldots+\frac{n p \cdot d n}{T o}\right], \text { where } n p m \text { is the number }
\end{gathered}
$$
of parasitoids dead that day, $d$ is the day the parasitoids died, $d n$ is the total number of days that there were deaths, and TMo is the total number of parasitoids dead in all days. On the other hand, $n p$ is the number of parasitoids that emerged that day, $d$ is the day the parasitoids emerged, $d n$ is the total number of days in which there was an emergence, and
To is the total of number of parasitoids that emerged every day.

\section{Statistical analysis}

The data obtained were subjected to the assumptions of homogeneity of variance (Bartlett test) and normality (Lilliefors test), and those that did not show normality or homogeneity were transformed by the formula $A R C=\left(A S E N\left(R A I Z\left(\left(n^{\circ}\right.\right.\right.\right.$ parâmetro $\left.\left.\left.) / 100\right)\right)\right)$, using Microsoft Office Excel ${ }^{\circledR}$, and then submitted to homogeneity and normality tests. The results were analyzed using the nonparametric Kruskal-Wallis test, and the different contact strategies of the parasitoid with the fungus (COF24 and COF72) were compared by the nonparametric Mann Whitney test, using the Bioestat 5.3 statistical program (Ayres, Ayres, \& Santos, 2007).

\section{Results and Discussion}

The longevity of adult T. podisi females exposed to $M$. anisopliae (14.1 days) and $B$. bassiana (13.4 days) was significantly reduced by 4.49 and 5.14 days, respectively, when compared to the control group (18.5 days) (Table 2).

\section{Table 2}

Longevity ( $\pm \mathrm{SE})$, in days, of adult females of Telenomus podisi exposed to treated surfaces. Temperature $26 \pm 2{ }^{\circ} \mathrm{C}, 12$ hours of photophase and $U, R, 75 \pm 10 \%$

$\begin{array}{cc}\text { Treatment } & \text { Longevity (days) } \\ \text { Control } & 18.5 \pm 0.35 \mathrm{a} \\ \text { Metarhizium anisopliae } & 14.1 \pm 0.35 \mathrm{~b} \\ \text { Beauveria bassiana } & 13.4 \pm 0.35 \mathrm{~b} \\ p & <0.05\end{array}$

Means ( \pm SE) followed by the same letter, lowercase in the column, do not differ according to the Kruskal Wallis test $(p<0.05)$. 
Although the longevity of adult $T$. podisi females was reduced, there was no reduction of parasitism in both contact strategies of the parasitoid with fungi (COF24 and COF72), compared to the control. There was also no significant difference in parasitism, on comparing the contact strategies used (Table 3).

\section{Table 3}

Percentage of parasitism in adult females of Telenomus podisi (in COF24 and COF72) exposed to treated surfaces and percentage of emergence of parasitized eggs. Temperature $26 \pm 2^{\circ} \mathrm{C}, 12$ hours of photophase and U.R. of $75 \pm 10 \%$.

\begin{tabular}{ccccc} 
& Treatment & COF24 & COF72 & \\
& Control & $61.6 \pm 6.11 \mathrm{aA}$ & $49.0 \pm 6.22 \mathrm{aA}$ & \\
Parasitism & Metarhizium anisopliae & $51.4 \pm 7.18 \mathrm{aA}$ & $34.2 \pm 6.33 \mathrm{aA}$ & $>0.05$ \\
$(\%)^{1}$ & Beauveria bassiana & $51.4 \pm 6.60 \mathrm{aA}$ & $43.6 \pm 6.31 \mathrm{aA}$ & \\
& $p$ & \multicolumn{2}{c}{$>0.05$} \\
Emergency & Control & $56,1 \pm 8,07 \mathrm{aA}$ & $46,1 \pm 6,49 \mathrm{aA}$ & $>0,05$ \\
$(\%)^{2}$ & Metarhizium anisopliae & $45,3 \pm 8,75 \mathrm{aA}$ & $10,3 \pm 2,15 \mathrm{bB}$ & $<0,05$ \\
& Beauveria bassiana & $53,5 \pm 8,12 \mathrm{aA}$ & $10,2 \pm 1,81 \mathrm{bB}$ & \\
& $p$ & $>0,05$ & $<0,05$ &
\end{tabular}

${ }^{3}$ COF24: Cards with 25 eggs of non-parasitized E. heros offered 24 hours after $T$. podisi female contact with sprayed surface.

${ }^{4}$ COF72: Cards with 25 eggs of non-parasitized $E$. heros offered 72 hours after female contact with sprayed surface. Means $( \pm \mathrm{SE}$ ) followed by the same letter, lowercase in the column, do not differ according to the Kruskal Wallis test $(p<0.05)$

Means ( \pm SE) followed by the same letter, capitalized on the line, do not differ according to the Mann Whitney test $(p<0.05)$.

Brown stink bug is one of the main pest insects of the soybean crop in Brazil (Associação Brasileira das Indústrias e Óleos Vegetais (ABIOVE), 2018), which requires constant phytosanitary application for its control, including products based on entomopathogenic fungi (Silva-Santana et al., 2021; Nora et al., 2021). Even though fungal-based biopesticides are less toxic than conventional chemical insecticides, they can affect non-target organisms such as egg parasitoids. In this study, it was observed that the evaluated products, based on $M$. anisopliae and $B$. bassiana, reduced the longevity of adult female T. podisi parentals.
Such reduction may be related to changes in walking behavior, cleaning and/or reduced feeding, which represent a greater energy expenditure for these insects. Energy expenditure is reported in the literature as a factor influencing egg parasitoid longevity (Pacheco \& Corrêa-Ferreira, 1998).

Regarding the emergence of $\mathrm{F} 1$ of $T$. podisi from the parasitized eggs, in the COF72 strategy, both fungi caused a significant reduction in the percentage of emergence, with $10.3 \%$ for $M$. anisopliae and $10.2 \%$ for $B$. bassiana, compared to the control (45.3\%). When comparing the two contact strategies 
between the parasitoid and the fungi, a significant reduction in the emergence of $\mathrm{F} 1$ T. podisi in COF72 was observed in relation to COF24 (Table 3). The emergence of $T$. podisi offspring tends to decrease naturally with the age of adult females, because at the time of copulation, the females store the sperm in the spermatheca. The condition of the male gametes (quality and quantity) is an important factor for reproduction and development of the parasitoids. In this context, older females will have sperms stored for longer and in smaller quantities (Cingolani, Greco, \& Liljesthröm, 2014; Cunningham, Farias, Nakagawa, \& Chambers, 1971).

In a similar study, M. anisopliae neither reduced the percentage of parasitism when applied to adult females of T. podisi, nor have a negative effect on offspring emergence (Agüero,Neves,\&Manuel,2014). This difference might be related to the $M$. anisopliae isolates used and/or their concentrations, which differ between the products used in both studies. In the same sense, the Metarril ${ }^{\circledR}$ and Boveril ${ }^{\circledR}$ products did not affect the emergence of Trichogramma pretiosum Riley (Hymenoptera: Trichogrammatidae) offspring (Amaro et al., 2015). It is important to note that the lethal and sublethal effects of entomopathogenic fungi vary according to the species of fungus tested, the isolate, the organism evaluated, the form of application, the concentration, and the time interval between application of entomopathogens and release of parasitoids, among other abiotic factors.

The adult-egg period, in days, of $T$. podisi offspring (male and female) emerged from $E$. heros eggs parasitized by $T$. podisi females exposed to entomopathogenic fungi was not reduced in both contact strategies of the parasitoid with the fungi (COF24 and COF72), compared with the respective controls. On the other hand, only for females in COF24, M. anisopliae significantly increased the egg-adult period (12.8), with respect to the control (12.3). When comparing the eggadult period of $T$. podisi offspring emerging from $E$. heros eggs parasitized by $T$. podisi females exposed to entomopathogenic fungi using the different strategies, a reduction is observed only in COF72. In case of females, M. anisopliae reduced the period (12 days), differing significantly from COF24 (12.8 days), while in case of males, $B$. bassiana reduced the period in COF72 (11.6 days), compared to COF24 (12.6 days) (Table 4).

The sex ratio of $T$. podisi offspring emerged from $E$. heros eggs parasitized by $T$. podisi females exposed to entomopathogenic fungi was not altered in both parasidoidfungal contact strategies (COF24 and COF72), nor in comparison between such strategies (Table 4). The results observed in the duration of the egg-adult period, despite showing significant differences, have variations of a few hours, which probably would not change the maintenance of the population in the agroecosystems (Potrich et al., 2009, 2015). Sex determination in offspring egg parasitoids, such as T. podisi, can be influenced by several factors, such as the age of the parental female and the quality of the host egg (Cingolani et al., 2014; Vinson, 1997). In this study, no change in sex ratio was observed, inferring that the age of the parental female was not a determining factor. Furthermore, the host eggs used (up to $96 \mathrm{~h}$ of age) did not receive any treatment that could alter their texture or nutritional composition. 


\section{Table 4}

Egg-adult period (days) and sex ratio ( \pm SE) of Telenomus podisi emerged from Euschistus heros eggs (in COF24 and COF72) parasitized by females exposed to treated surfaces. Temperature $26 \pm 2^{\circ} \mathrm{C}, 12$ hours of photophase and U.R. of $75 \pm 10 \%$

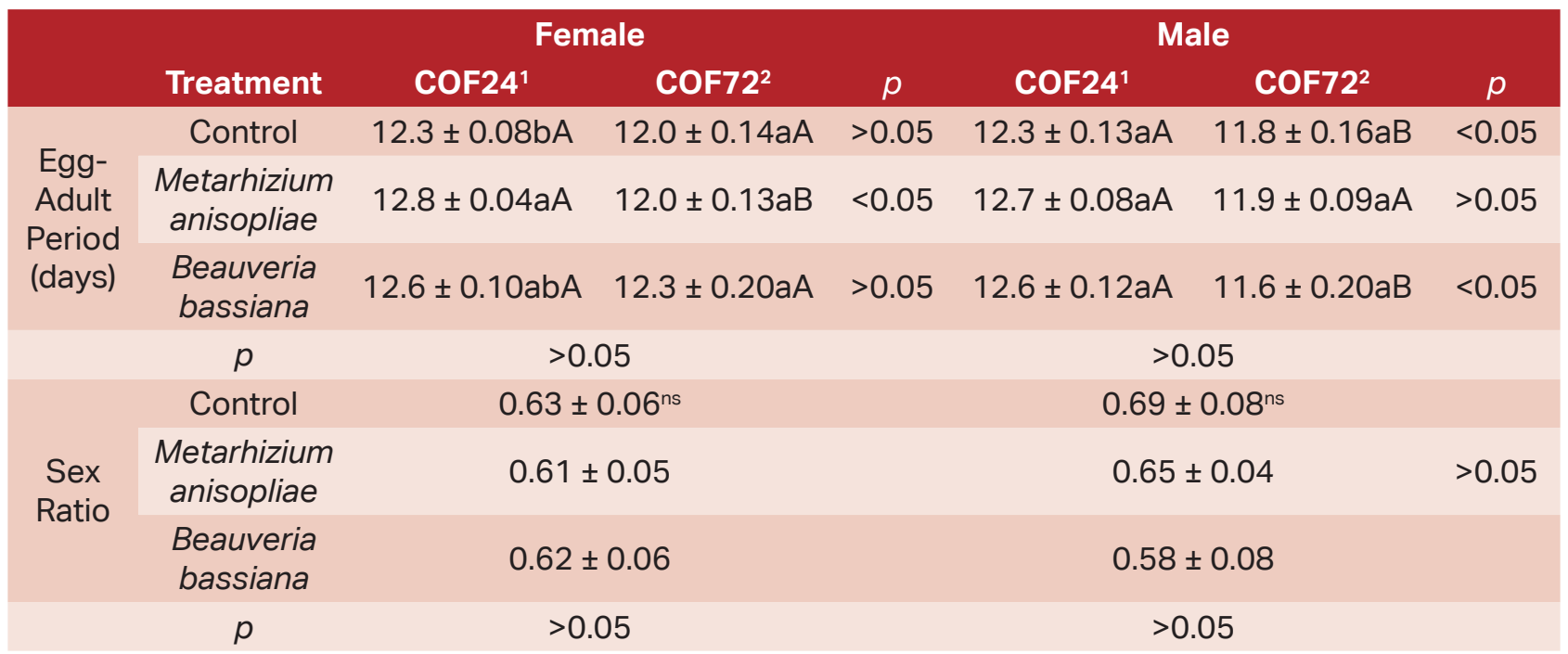

${ }^{1}$ COF24: Cards with 25 eggs of non-parasitized E. heros offered to females 24 hours after T. podisi female contact with the sprayed surface.

${ }^{2}$ COF72: Cards with 25 eggs of non-parasitized $E$. heros offered to females 72 hours after $T$. podisi female contact with the sprayed surface.

ns = not significant Kruskal Wallis (columns) and Mann Whitney (rows) tests.

Means ( \pm SE) followed by the same letter, lowercase in the column, do not differ according to the Kruskal Wallis test $(p<0.05)$.

Means $( \pm S E)$ followed by the same letter, capitalized on the line, do not differ according to the Mann Whitney test $(p<0.05)$.

Some negative effects of the products, based on entomopathogenic fungi tested here, on T. podisi were observed. However, such fungi can be considered selective for T. podisi adults. This is because in these experiments, the parasitoids were placed in extreme conditions of contact ( 24 and 72 consecutive hours) with the products, at the recommended concentrations for use in the field, without changing the parasitism. According to Potrich et al., (2009) parasitism is considered the main factor for the efficiency of parasitoids in the field. Battisti et al. (2020) also observed that when the parental females of $T$. podisi are exposed to Metarril ${ }^{\circledR}$ and Boveril ${ }^{\circledR}$ products, applied on the host eggs, the percentage of parasitism and the percentage of offspring emergence are not affected. It is important to point out that these extreme conditions of contact will hardly occur in the field, as the parasitoid can fly and seek other environments and/or its host's eggs. Thus, we suggest the possible use of both control strategies (the fungi tested here and the parasitoid), since both act at different stages of $E$. heros life and might be complementary for controlling this and/or acting on different targets. Although laboratory studies show the selectivity of the fungi evaluated on adults of T. podisi, field studies are important to define the best strategies for joint use. 


\section{Acknowledgements}

The authors thank the CNPQ (National Council for Scientific and Technological Development) for the financial support for the development of the project (process 424078/2016-3), CAPES (Coordination for the Improvement of Higher Education Personnel) for granting a scholarship for the first author, and Federal Technological University of Paraná (UTFPR) and the company GEBANA BRASIL Cataratas do Iguaçu Produtos Orgânicos Ltda for all their support in carrying out the work.

\section{Conflict of Interest Declaration}

The authors declare no conflict of interest.

\section{Authors' Contributions}

All authors contributed to the development of the work, from conception to writing the manuscript. All authors critically reviewed the manuscript and approved the final version.

\section{References}

Agüero, F., Neves, M. A. O. J., \& Manuel, P. (2014). Seletividade de Metarhizium anisopliae a Telenomus podisi (Hymenoptera: Scelionidae). Investigación Agraria, 16(1), 21-28. Recuperado de http://www.agr. una.py/revista/index.php/ria/article/ view/276

Amaro, J. T., Bueno, A. F., Pomari-Fernandes, A. F., \& Neves, P. M. O. J. (2015). Selectivity of organic products to Trichogramma pretiosum Riley (Hymenoptera: Trichogrammatidae). Neotropical Entomology, 44(5), 489-497. doi: 10.1007/ s13744-015-0317-2

Associação Brasileira das Indrústrias e Óleos Vegetais (2018). Estatísticas. Recuperado de https://abiove.org.br/site/_FILES/ Portugues/01032018-131415-01_03_ 2018_-_nota_estatisticas_complexo_ soja.pdf

Ayres, M., Ayres, D., \& Santos, A. A. S. (2007). Bioestat: aplicações estatísticas nas áreas das ciências biológicas e médicas. Belém: MCT-CNPq.

Battisti, L., Warmling, J. V., Vieira, C. F., Oliveira, D. H. R., Lima, Y. R. A., Potrich, M.,... Lozano, E. R. (2020). Side effects of organic products on Telenomus podisi (Hymenoptera: Platygastridae). Journal of Economic Entomology, 113(4), 16941701. doi: 10.10.1093/jee/toaa119

Bueno, R. C. O. de F., Bueno, A. de F., Parra, J. R. P., Vieira, S. S., \& Oliveira, L. J. de. (2010). Características biológicas e capacidade de parasitismo de Trichogramma pretiosum Riley (Hymenoptera, Trichogrammatidae) em ovos de Spodoptera frugiperda (J. E. Smith) (Lepidóptera, Noctuidae). Revista Brasileira de Entomologia, 54(2), 322-327. doi: $10.1590 / S 0085-562620100002000$ 16

Cingolani, M. F., Greco, N. M., \& Liljesthröm, G. G. (2014). Effect of telenomus podisi, trissolcus urichi, and Trissolcus basalis (Hymenoptera: Platygastridae) age on attack of Piezodorus guildinii (Hemiptera: Pentatomidae) Eggs. Environmental Entomology, 43(2), 377-383. doi: 10.1603/ EN13250 
Cunningham, R., Farias, G., Nakagawa, S., \& Chambers, D. (1971). Reproduction in the mediterranean fruit fly: depletion of stored sperm in females. Annals of the Entomological Society of America, 64(1), 312-313. doi: 10.1093/aesa/64.1.312

FIBL - Research Institute of Organic Agriculture \& IFOAM - The International Federation of Organic Agriculture Movements (2019). The world of organic agriculture statistic and emerging trends 2019. Retrieved from https://ciaorganico. net/documypublic/486_2020-organicworld-2019.pdf

Magalhães, B. (1998). Controle microbiano de insetos. In S. B. Alves (Ed.), Interações entre entomopatógenos, parasitoides e predadores (pp. 195-216). São Paulo: FEALQ.

Nodari, R. O., \& Guerra, M. P. (2015). A agroecologia: estratégias de pesquisa e valores. Estudos Avancados, 29(83), 183-207. doi: 10.1590/S0103-40142015 000100010

Nora, D. D., Piovesan, B. C., Bellé, C., Stacke, R. S., Balardin, R. R., \& Guedes, J. V. C. (2021). Isolation and evaluation of entomopathogenic fungi against the neotropical brown stink bug Euschistus heros (F.) (Hemiptera: Pentatomidae) under laboratory conditions. Biocontrol Science and Technology, 31(1), 22-34. doi: 10.1080/09583157.2020.1826904

Pacheco, D. J. P., \& Corrêa-Ferreira, B. S. (1998). Potencial reprodutivo e longevidade do parasitóide Telenomus podisi Ashmead, em ovos de diferentes espécies de percevejos. Anais da Sociedade Entomológica do Brasil,
27(4), 585-591. doi: 10.1590/s0301-80 591998000400011

Pacheco, D. J. P., \& Corrêa-Ferreira, B. S. (2000). Parasitismo de Telenomus podisi Ashmead (Hymenoptera: Scelionidae) em populações de percevejos pragas da soja. Anais da Sociedade Entomológica do Brasil, 29(2), 295-302. doi: 10.1590/ s0301-80592000000200011

Parra, J. R. P. (2014). Biological control in Brazil: an overview. Scientia Agricola, 71(5), 420429. doi: 10.1590/0103-9016-2014-0167

Parra, J. R. P. (2019). Controle biológico na agricultura brasileira. Entomological Communications, 1. doi: 10.37486/26751305.ec01002

Polanczyk, R. A., Pratissoli, D., Dalvi, L. P., Grecco, E. D., \& Franco, C. R. (2010). Effect of Beauveria bassiana (Bals.) Vuillemin and Metarhizium anisopliae (Metsch.) Sorokin on the biological parameters of Trichogramma atopovirilia Oatman \& Platner (Hymenoptera: Trichogrammatidae). Ciência e Agrotecnologia, 34(6), 1412-1416. doi: 10.1590/s1413-70542010000600008

Potrich, M., Alves, L. F. A., Haas, J., Silva, E. R. L. da, Daros, A., Pietrowski, V., \& Neves, P. M. O. J. (2009). Selectivity of Beauveria bassiana and Metarhizium anisopliae to Trichogramma pretiosum Riley (Hymenoptera: Trichogrammatidae). Neotropical Entomology, 38(6), 822826. doi: 10.1590/s1519-566x2009000 600016

Potrich, M., Alves, L. F. A., Lozano, E., Roman, J. C., Pietrowski, V., \& Neves, P. M. O. J. (2015). Interactions between Beauveria bassiana and Trichogramma pretiosum 
under laboratory conditions. Entomologia Experimentalis et Applicata, 154(3), 213221. doi: $10.1111 /$ eea. 12272

Silva, G. V., Bueno, A. F., Neves, P. M. O. J., \& Favetti, B. M. (2018). Biological characteristics and parasitism capacity of Telenomus podisi (Hymenoptera: Platygastridae) on eggs of Euschistus heros (Hemiptera: Pentatomidae). Journal of Agricultural Science, 10(8), 210-220. doi: 10.5539/jas.v10n8p210

Silva-Santana, M. F., Alves, L. F., Ferreira, T. T., \& Bonini, A. K. (2021). Selection and characterisation of Beauveria bassiana fungus and their potential to control the brown stink bug. Biocontrol Science and Technology, 76(3), 1-13. doi: 10.1080/09583157.2021.1970716

Sistema de Agrotóxicos Fitossanitários (2021). Relatório de agrotóxicos. Recuperado de http://agrofit.agricultura.gov.br/agrofit_ cons/principal_agrofit_cons
Tognon, R., Sant'Ana, J., \& Jahnke, S. M. (2013). Aprendizagem e memória de Telenomus podisi (Hymenoptera, Platygastridae). Iheringia - Serie Zoologia, 103(3), 266271. doi: 10.1590/S0073-47212013000 300009

van Lenteren, J. C., Bolckmans, K., Köhl, J., Ravensberg, W. J., \& Urbaneja, A. (2018). Biological control using invertebrates and microorganisms: plenty of new opportunities. BioControl, 63(1), 39-59. doi: 10.1007/s10526-017-9801-4

Vinson, B. (1997). Comportamento de seleção hospedeira de parasitoides de ovos, com ênfase na família Trichogrammatidae. In J. R. P. Parra, \& R. A. Zucchi (Eds.), Trichogramma e o controle biológico aplicado (pp. 324). Piracicaba: FEALQ. 
